Chirurgia (2021) 116: 66-74

No. 1, January - February

Copyright@ Celsius

http://dx.doi.org/10.21614/chirurgia.116.1.66

\title{
Presurgical Stratification of Thyroid Nodules - Is it really Needed? Current Guidelines versus Real Life
}

\author{
Andreea Borlea', Amadeus Dobrescu²*, Alis Dema ${ }^{3}$, Mărioara Cornianu ${ }^{3}$, Fulger Octavian Lazăr ${ }^{2}$, Dan Brebu² \\ 'Department of Internal Medicine II, University of Medicine and Pharmacy "Victor Babeș", Timișoara, Romania \\ 2Department of Surgery, University of Medicine and Pharmacy "Victor Babeș", Timișoara, Romania \\ 32Department of Pathology, University of Medicine and Pharmacy "Victor Babeș", Timișoara, Romania
}

${ }^{*}$ Corresponding author:

Amadeus Dobrescu, MD

Department of Surgery

University of Medicine and Pharmacy

"Victor Babeș", Timișoara, Romania

E-mail: amadeusdobrescu@yahoo.com

\section{Rezumat}

Evaluarea preoperatorie a nodulilor tiroidieni - este cu adevărat necesară? Ghiduri curente versus viaț reală

Introducere: Chirurgia tiroidiană are numeroase indicații, atât pentru patologiile benigne, cât şi pentru cele maligne. $\mathrm{O}$ evaluare pre-operatorie completă ghidează selecția cazurilor şi determină complexitatea tipului de intervenție. Reducerea numărului de tiroidectomii printr-o selecție clinică atentă ar putea reduce costurile de spitalizare, precum şi complicațiile postoperatorii şi apariția hipotiroidismului iatrogen. Obiectivul acestui studiu a fost evaluarea retrospectivă a motivelor de internare în spital a pacienților în vederea chirurgiei tiroidiene şi estimarea necesității tiroidectomiilor totale.

Material şi Metodă: Studiul a inclus pacienții internați în cele trei departamentele de chirurgie din cadrul Spitalului Județean de Urgență "Pius Brinzeu" Timişoara, între 1 ianuarie 2018 şi 31 decembrie 2019 (2 ani).

Rezultate:A fost efectuat un număr total de 1036 de tiroidectomii la 1027 de pacienti. Cazurile au fost analizate retrospectiv, comparând diagnosticul preoperator cu rezultatul histopatologic. În 326/824 de cazuri de tiroidectomie totală s-a ridicat suspiciunea de malignitate, fenomene de compresiune sau autonomie funcțională. S-au depistat 338 de cazuri de cancer din cei 1027 de pacienți (32,92\%), acestea incluzând şi 39 de leziuni "de graniță". Dintre malignități, $80,7 \%$ au fost carcinoame papilare tiroidiene. Evaluarea preoperatorie curentă a generat un număr de 475 de cazuri la care diagnosticul preoperator a fost diferit de cel 
postoperator. Acest fenomen a fost observat atât în cazul tiroidectomiilore totale, cât şi în cel al lobectomiilor: la, $22,8 \%$ dintre lobectomii s-au confirmat a fi cancere tiroidiene.

Concluzii: Rezultatele noastre subliniază importanța unei abordări multidisciplinare şi a unei evaluări preoperatorii standardizate, clinică, biochimică şi ecografică, la pacienții cu indicație de tiroidectomie, pentru a se evita intervențiile chirurgicale care nu sunt necesare.

Cuvinte cheie: tiroidectomie, noduli tiroidieni, cancer tiroidian, puncție-aspirație cu ac fin, tratament excesiv

\section{Abstract}

Background: Thyroid surgery has various benign and malignant indications. A complete pre-surgical evaluation guides the selection of cases and determines the appropriate extent of the intervention. Minimizing the number of unneeded thyroidectomies could reduce hospitalization costs, as well as post-surgery complications and iatrogenic hypothyroidism. The aim of this study was to retrospectively evaluate the presenting reasons of patients admitted to the hospital for thyroid surgeries and to estimate the need of total thyroidectomies.

Methodology: The study included patients admitted in all three Surgical Departments in Timisoara Emergency County Hospital, between January $1^{\text {st }} 2018$ and December $31^{\text {st }} 2019$ (2 years).

Results: A number of 1036 thyroid surgeries had been performed in 1027 patients and were retrospectively analyzed, comparing the pre-surgical diagnosis with the pathology report. Suspicion of malignancy, compression or functional autonomy was described in 326 /824 total thyroidectomy cases. Cancer was detected in 338 out of the 1027 patients (32.92\%), including 39 borderline lesions. A proportion of $80.7 \%$ were papillary thyroid cancers. The current presurgical evaluation generated a number of 475 cases displaying differences between the presurgical and postsurgical diagnostic. The phenomenon was observed both in total thyroidectomy and in lobectomy interventions: $22.8 \%$ of the lobectomies were diagnosed with thyroid cancer.

Conclusion: Our findings confirm that a reliable multidisciplinary approach with standardized presurgical clinical, biochemical and ultrasound evaluation is crucial in patients with indication for thyroid surgery, in order to avoid unnecessary surgeries.

Key words: thyroidectomy, thyroid nodules, thyroid cancer, fine-needle aspiration, overtreatment

\section{Introduction}

Thyroid surgeries have progressed in the past decades to a very safe intervention, easily performed in the case of an experienced surgeon, with great outcomes and low incidence of complications such as hypocalcemia or laryngeal recurrent nerve damage $(1,2)$. While medical treatment options or radioactive iodine (RAI) ablation only provides partial reduction of autonomous goiter, with long term hyperthyroidism relapse, surgical intervention offers a definitive cure. Indications of thyroid surgery are numerous, including nodules with malignancy risk (defined forom the anamnestic, clinical, molecular or ultrasonographic point of view), functional autonomy, large goiters leading to local compressive symptoms or subjective, cosmetic reasons (3-6). Subtotal thyroidectomy was a largely used procedure in the past, but its linked recurrence has lead to recommending complete lobectomy from the start or total thyroidectomy. The extent of surgery is decided by a complete clinical evaluation comprising imaging and laboratory evaluation, thus a multidisciplinary approach 
including a thyroid surgeon, an endocrinologist and/or a radiologist is crucial $(7,8)$. Nodular goiter is increasing in prevalence, its clinical importance being related mainly to correctly identifying malignancy (9). The incidence of thyroid cancer is on the rise, the early detection of papillary thyroid microcarcinomas (PTMC) playing an important role $(10,11)$. Certain groups are considered to present greater risk for cancer, such as children, young adults, patients with a personal history of neck irradiation (12). In the recent years, a new category of borderline thyroid lesions was defined by the World Health Organization (WHO). This division requires attention in monitoring, given its uncertain evolution and it includes: non-invasive follicular thyroid neoplasm with papillary-like features (NIFT$\mathrm{P})$, well-differentiated tumors of uncertain malignant potential (WDT-UMP) and follicular tumors of uncertain malignant potential (FT-UMP) $(13,14)$.

Neck ultrasound currently represents the most sensitive and cost-effective imaging method for evaluating thyroid morphology and it is widely available $(4,15,16)$. Efforts of thyroidologists merged into designing standardized presurgical risk-stratification algorithms (17). New technologies, such as sonoelastography may add valuable information to the diagnosis strategy (18-22) increasing the diagnostic quality and accuracy. Fine-needle aspiration (FNA) biopsy represents the next step in the evaluation of suspicious thyroid nodules; it is minimally invasive and in the majority of cases it provides a clear answer whether to observe or refer the patient to surgery (23), by using the Bethesda reporting system $(4,16,24)$. The number of negative FNA results is small, up to $3-5 \%$ (16) but the intermediate cytology category, Bethesda III and IV, represents a cornerstone of the FNA use in presurgical thyroid nodule evaluation. High risk circumstances, from the anamnestic, clinical, ultrasound or molecular point of view define the type of surgical approach in such cases $(24,25)$

Still, due to the lack of availability, the fear of procedure or the limitations of the method, patients are directed to surgery departments for thyroidectomy without prior FNA.

The present study aims to assess the proportion of cases,in which a complete presurgical evaluation was performed before being addressed for thyroid surgery, by analyzing the reasons presented by patients with thyroid pathology who were admitted to the surgical departments. The study also attempts to estimate the need of a precise presurgical risk stratification, so to diminish the amount of unneeded surgeries, as well as to enhance the surgical effort.

\section{Material and Method}

\section{Subjects and Data Collection}

The study was conducted retrospectively and engaged an analysis of the thyroid surgical procedures performed over a period of two years (between January 1st 2018 and December $31^{\text {st }} 2019$ ) in all three Departments of Surgery ( $1^{\text {st }}$ Department of Surgery, $2^{\text {nd }}$ Department of Surgery and Emergency Surgery Clinic) comprising more than 120 beds, from Timisoara County Hospital "Pius Brinzeu", in Romania. All thyroid surgeries were considered in the analysis, including total thyroidectomies, unilateral lobectomies and reoperations for complete thyroidectomy after malignant findings or recurrence of suspicious nodules following initial lobectomy. All operations were performed on adult patients by surgeons with different levels of experience in thyroid surgery. A pathology report was available in all cases.

Patient data were collected retrospectively from the hospital records and included personal history, presurgical diagnosis, laboratory assessment confirming the indication, the extent of the surgical intervention and details from the pathology report.

\section{Presurgical Evaluation}

Various clinicians in Western Romania performed investigations in order to establish 
the presurgical diagnosis. No unitary presurgical risk stratification model was used.

Data from ultrasound evaluation were not available in all cases, thus the admission diagnosis was considered for comparison. FNA results were analyzed where available; Molecular testingT was not performed in any of the FNA cases.

\section{Surgical Treatment}

Before performing thyroid surgery, the patients with hyperthyroidism received specific treatment until achieving euthyroid status. Thyroidectomy was performed under general anesthesia and consisted in total thyroidectomy or thyroid lobectomy with isthmectomy. The removal of all thyroid tissue was performed in patients with severe hyperthyroidism and nodular thyroid disease. Great care was taken in order to preserve the parathyroid glands, the recurrent laryngeal nerve and the external branch of the superior laryngeal nerve. Subtotal thyroidectomy was not performed due to the high risk of recurrence and also to the autoimmune mechanisms implicated in the etiology of hyperthyroidism.

Thyroid lobectomy was performed by removing the entire thyroid lobe. The branches of the inferior thyroid artery are ligated before they enter the thyroid capsule, avoiding the ligation of the artery itself. In doing so, the recurrent laryngeal nerve was preserved and also devascularization of the parathyroid glands was avoided. Modified radical neck dissection implies a total thyroidectomy followed by the excision of the central lymph nodes, perithyroidal lymph nodes, lymph nodes from the tracheoesophageal groove and also lymph nodes found along the carotid artery and the internal jugular vein.

The extent of the disease (tumor size, extrathyroidal extension, lymph node involvement, patient's age) determines the extent of surgery: thyroid lobectomy or total thyroidectomy. Cases with the involvement of cervical lymph nodes, diagnosed by pre- operative ultrasound or CT scan, underwent a therapeutic neck dissection (central and lateral compartments) at the time of thyroidectomy. For tumors under $1 \mathrm{~cm}$ and for incidentally diagnosed tumors (of under $5 \mathrm{~mm}$ ), which are rarely accompanied by lymph node metastases, thyroid lobectomy with isthmectomy was considered the treatment of choice.

In patients with a suspected follicular thyroid carcinoma, neither fine needle biopsy, nor intraoperative histologic evaluation can certify the presence or absence of malignancy. Patients diagnosed postoperatively with carcinomas underwent a second surgery for thyroid totalization.

\section{Pathology Report}

In all cases, the final confirmation was basedon the pathology analysis, the golden standard for diagnosis. The pathology examination was performed using hematoxylin-eosin staining and/or immunohistochemistry. The cases that presented borderline thyroid tumors were considered in our final analysis as malignant lesions, given their uncertain evolution.

\section{Statistical Analysis}

Data were collected and analyzed using MedCalc Software, version 12.5.0.0 (MedCalc program, Belgium) and SPSS, version 17.0 (IBM Statistics, USA). The distribution of the continuous variables was cheked using the Kolmogorov-Smirnov test. For continuous variables with normal distribution, the results were reported as mean value and standard deviation, and as median values and range intervals for variables with non-normal distribution. All categorical variables were expressed as the proportion of cases with or without the defined characteristic. The Student's t-test was applied for analyzing the differences between groups for continuous variables with a normal distribution; nonparametric tests were used for variables with a non-normal distribution: the Mann-Whitney 
U-test. A threshold for revealing statistical significance was accepted for a $\mathrm{p}$-value $<0.05$.

\section{Results}

Out of the total 1036 thyroid interventions selected for analysis, 9 were reinterventions on patients that were previously counted in the analysis, resulting in a number of 1027 operated subjects. The majority of patients were females: $928(90.36 \%)$ and only 99 were males $(9.64 \%)$, with a mean age of $53.8 \pm 13$ years.

Concerning the extent of surgery, total thyroidectomy was performed in 824 cases and lobectomy in 180. 32 cases were redo interventions, 9 of which were on the same patient. The indications for redo interventions was either thyroid cancer (18 cases) or nodular goiter long term relapse (14 cases).

\section{Reasons for Surgery}

An important percentage of cases presented the vast diagnosis of nodular goiter $(674 ; 65 \%)$. All indications for surgery as reported in the patient files are displayed in Table 1.

\section{Pathology Findings}

The pathology report was examined in all cases. Benign findings were described in 689 of the patients $(67 \%)$. The majority of the benign findings ( $65.3 \%$ of this group) proved to be thyroid adenomas. A detailed characterization for pathology diagnosis in the benign category is presented in Table 2.

The malignancy group consisted of 338 cancers (32.9\%). Differences were noted regarding cancer prevalence between the operated males and females and also on different age groups. The subjects were divided into subgroups according to their age: younger than 30 years: $58 / 1027 ; 31-50$ years: $343 / 1027$; $51-65$ years: $425 / 1027$; older than 65: 201/1027. Significant differences in the prevalence of malignancy were found between males and females. Regarding age groups, significant differences were noted only
Table 1. The indications for thyroid surgery in the group of study

\begin{tabular}{lc}
\hline Surgical Indication & No. of patients \\
\hline NG & 674 \\
$\quad$ NG + Suspicious FNAC & 121 \\
$\quad$ Compression & 54 \\
\hline HTG & 43 \\
\hline GD 38 & 19 \\
$\quad$ GD + nodules & 55 \\
\hline CAT \pm nodules & 32 \\
\hline Redo thyroidectomy & \\
\hline NG - nodular goiter; FNAC - fine-needle aspiration cytology; \\
HTG - hyperthyroid goiter; GD - Graves' disease; \\
CAT - chronic autoimmune thyroiditis; Redo - Completion thyroidectomy \\
for remnant parenchyma or partial thyroidectomy
\end{tabular}

Table 2. Benign pathology report findings in the study group

\begin{tabular}{lcc}
\hline Pathology diagnosis & No. of cases & Percentage /total cases \\
\hline NG & 450 & $43.8 \%$ \\
\hline CAT & 152 & $14.8 \%$ \\
\hline GD & 55 & $5.3 \%$ \\
\hline HTG & 32 & $3.1 \%$ \\
\hline Total benign cases & 689 & $67 \%$
\end{tabular}

NG - nodular goiter; CAT - chronic autoimmune thyroiditis;

GD - Graves' disease; HTG -hyperthyroid goiter

in the female group, when comparing women younger than 30 years old with older women. Table 3 illustrates the mentioned findings.

A clear malignancy was defined in 299 of the reports $(29.1 \%)$ and borderline thyroid tumors (NIFT-P, WDT-UMP and follicular FT-UMP) in 39 of the cases $(3.8 \%)$. The distribution of cancers incorporated an important share of papillary (133; 39\%) and micropapillary (140; 41\%) thyroid carcinomas; also, the borderline category was well represented in the study group $(39 ; 12 \%)$. The malignancy repartition is displayed in Fig. 1.

Table 3. Differences in the prevalence of cancer in females versus males and age groups

\begin{tabular}{cccc}
\hline Gender/Age distribution & Cancer & Total & p-value \\
\hline Women & $283(30.5 \%)$ & 928 & $\mathrm{p}<0.001$ \\
$<30$ & $8(16 \%)$ & 50 & $\mathrm{p}<0.05$ \\
$31-50$ & $102(32.9 \%)$ & 310 & $\mathrm{p}=0.293$ \\
$51-65$ & $117(30.3 \%)$ & 386 & $\mathrm{p}=0.928$ \\
$>65$ & $56(30.8 \%)$ & 182 & $\mathrm{p}=0.991$ \\
\hline Men & $55(55.6 \%)$ & 99 & $\mathrm{p}<0.001$ \\
$<30$ & $1(12.5 \%)$ & 8 & $\mathrm{p}=0.78$ \\
$31-50$ & $16(48.5 \%)$ & 33 & $\mathrm{p}=0.17$ \\
$51-65$ & $25(64.1 \%)$ & 39 & $\mathrm{p}=0.24$ \\
$>65$ & $13(68.4 \%)$ & 19 & $\mathrm{P}=0.31$ \\
\hline
\end{tabular}




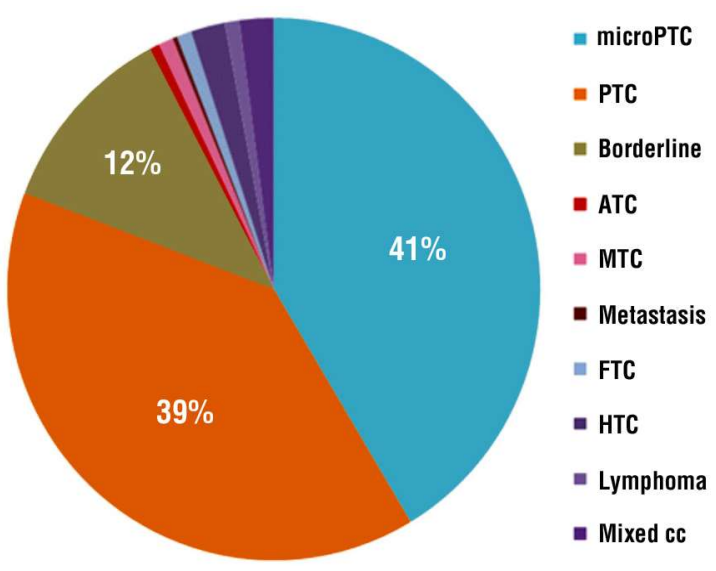

Figure 1. Distribution of malignancy types in the cancer group. PTC = papillary thyroid cancer, microPTC = micropapillary thyroid cancer, ATC = anaplastic thyroid cancer, $\mathrm{MTC}=$ medullary thyroid cancer FTC = Follicular thyroid cancer, HTC = Hürthle cell thyroid cancer, Mixed $\mathrm{CC}=$ coexistence of multiple types of thyroid cancers

Another analyzed aspect was related to the distribution of cancers in cases with different indications for the extent of surgery, as detailed in Table 4. A percentage of $22.8 \%$
Table 4. Distribution of detected malignancies in lobectomy/thyroidectomy cases

\begin{tabular}{lccc}
\hline & Cancer & Benign & Total \\
\hline Lobectomy & $41(22.8 \%)$ & 139 & 180 \\
\hline Total Thyroidectomy & $288(35 \%)$ & 536 & 824 \\
\hline Totalization (redo) & $9(28.1 \%)$ & 23 & 32 \\
\hline
\end{tabular}

cancers were detected in the lobectomy group, while $65 \%$ of the total thyroidectomies proved benign.

Discordances between the presurgical diagnosis and the pathology report were detected in 475 of cases $(46.2 \%)$. Fig. 2 presents the comparison of the clinical diagnosis indicating surgery and the final pathology report diagnosis.

The agreement between pre- and postsurgical diagnosis is further detailed in Table 5 .

\section{Discussion}

The management strategy in thyroid pathology has indeed evolved in the past years. Efforts for developing clear guidelines were addressed by
Presurgical diagnosis

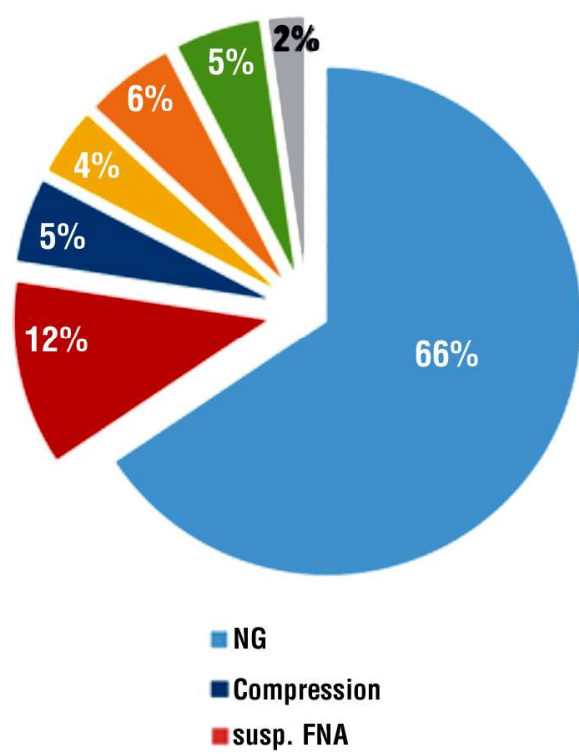

VS Pathology report

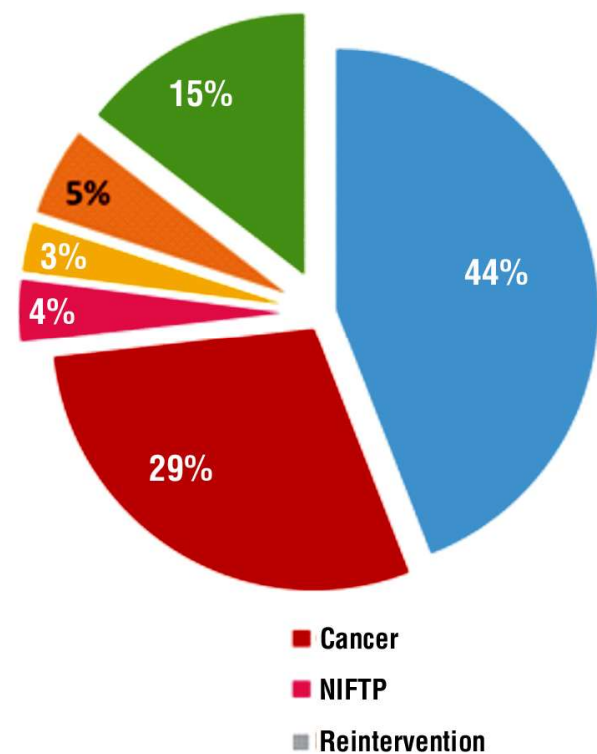

Figure 2. Diagnostic comparison: preoperative diagnosis versus pathology report.

NG - nodular goiter; NIFT-P - non-invasive follicular thyroid neoplasm with papillary-like features;

FNA - fine-needle aspiration; HTG - hyperthyroid goiter; GD - Graves' disease; CAT - chronic autoimmune thyroiditis. 
Table 5. The correspondence between presurgical diagnosis and pathology report findings

\begin{tabular}{|c|c|c|c|c|c|c|}
\hline Presurgical dg./ Pathology report. & Benign NG & CAT & GD & HTG & NIFT-P & Cancer \\
\hline $\mathrm{NG}(\mathrm{n}=674)$ & 363 & 110 & 6 & 1 & 25 & 169 \\
\hline Suspect FNAC $(n=121)$ & 47 & - & - & - & 9 & 65 \\
\hline Compression NG $(n=54)$ & 26 & 4 & - & - & 1 & 23 \\
\hline HTG $(n=43)$ & - & 2 & 8 & 29 & - & 4 \\
\hline CAT \pm nodules $(n=55)$ & 3 & 33 & 1 & 1 & 2 & 17 \\
\hline $\mathrm{GD} \pm$ nodules $(n=57)$ & - & - & 40 & 1 & 2 & 14 \\
\hline
\end{tabular}

both surgical and clinical endocrine societies $(7,26-29)$. On the other side, the development of ultrasound machines and the increase in detection of thyroid lesions strengthen the threat of overtreatment (30).

In the nodular goiter group, out of the total 892 preoperative diagnosis of NG included in our analysis, only $218(24.4 \%)$ presented a well defined indication for surgery, counting compression, suspect/malignant cytology result or hyperthyroidism. In this group $29.2 \%$ of the nodules were proved malignancies postoperatively. Interestingly, the compressive group presented an important malignancy rate of $42.6 \%$, probably also explained by an increased size of the lesions (31).

In 110 cases, the pathology report showed that simple CAT was misdiagnosed, clinically or on US evaluation, as nodular goiter. Rare findings included one patient with metastasis from pulmonary neoplasia and 3 cases with lymphomas (one of them was presurgically suspected to be anaplastic thyroid cancer). Cosmetic reasons were not clearly defined in the patient files and were not taken into consideration in the investigation, thus we probably missed a small number of patients reaching the surgery department with aesthetic discontent.

Risk identification from the anamnestic or clinical point of view is mandatory (7). Presurgical ultrasound evaluation and risk stratification shows excellent accuracy for conventional US (17), especially when combined with elastography assessment $(18,19,20)$. Cytological evaluations are also widely recommended $(16,23)$. Presurgical extensive evaluation is needed in order to reduce the unnecessary number of surgical procedures. However, the great number of thyroid cancers cases, observed in our series, does justify the radical surgical approach, as the method of choice, in cases with uncertain presurgical evaluation made by the endocrinologist, radiologist or internal medicine specialist.

A recent study evaluated the histology of benign FNA (Bethesda II) nodules larger than $4 \mathrm{~cm}$, reporting a $10.4 \%$ rate of thyroid cancer in this group (5). This confirms the limitation of FNA usefulness performed on large thyroid masses. Another important limitation is represented by indeterminate cytology findings. In these cases, the management decision is clearly debatable, some patients could benefit from thyroid surgeries, others that associate low US risk may be only periodically monitored $(24,25)$.

Regarding patients with Graves' disease, the pathology diagnosis confirmed in all cases the presurgical indication. Nevertheless, the preponderance of associated cancerous lesions in this group was notable. Malignancy was detected in 40\% (16 cases) of the operated GD patients, confirming the higher association of thyroid caner in the nodular forms of Graves' disease, urging the need of correct and complete presurgical diagnostic. It is worth mentioning that $19 / 38$ of these patients were indicated to perform surgery because of the association of nodules. A meta-analysis on thyroid carcinoma in Graves' disease found that in patients with GD, the coexistence of thyroid nodules increases the chances of 
cancer five times compared to cases without nodules (32).

Establishing the appropriate extent of surgery from the beginning is attributed to the clinician's priorities. Current guidelines, such as the 2020 American Association of Endocrine Surgeons (AAES) guideline, recommends lobectomy only in cases with unilateral nodule and proven benign findings by FNA cytology, or in cases of isolated micropapillary carcinoma with low risk ultrasound characteristics. Bethesda III cytology (follicular lesion of undetermined significance/atypia of undetermined significance) cases can undergo lobectomy only in the absence of any risk clues, from the anamnestic, clinical, ultrasound and, ideally, molecular point of view (28). Performing lobectomy without FNA is not recommended in any circumstance $(26,28)$. Extensive surgery is required only in some oncologic cases, increasing the rate of postoperative complications and influencing the quality of life (33).

Undoubtedly, the lobectomies in our group of study exceeded guideline indications. Cancer was detected in 41/180 (22.8\%) cases, which led to reoperation in 18 high-risk/multifocal lesions (4) in the lobectomy group, which could have benefitted from initial total thyroidectomy with a correct preoperative assessment.

\section{Conclusions}

Our findings confirm that, in the case of thyroid pathology requiring surgical management, it is crucial to perform a proper presurgical multidisciplinary evaluation that involves a clinical endocrinologist, an experienced endocrine or general surgeon and in some cases a radiologist or clinical oncologist.

This team-based approach is assumed to correctly identify the cases that truly benefit from surgical intervention and decide from the start the extent of surgery that favours each patient individually, resulting in minimized hospital costs, fewer reoperations and less postsurgical potential complications, avoiding the unnecessary surgeries.
In the presence of nodular thyroid pathology, total thyroidectomy should be considered in the absence of a complete presurgical risk assessment and stratification, by means of ultrasound, elastography or cytology evaluation.

\section{Conflict of Interest}

The authors declare no conflicts of interests.

\section{Ethics Approval}

For performing this study ethical approval was obtained - Emergency County Hospital "Pius Brinzeu" Timisoara, Local Ethics Comittee no 211/November 17, 2020.

\section{References}

1. Adam MA, Thomas S, Youngwirth L, Hyslop T, Reed SD, Scheri RP, et al. Is there a minimum number of thyroidectomies a surgeon should perform to optimize patient outcomes? Ann Surg. 2017; 265(2):402-407.

2. Loyo M, Tufano RP, Gourin CG. National trends in thyroid surgery and the effect of volume on short-term outcomes. Laryngoscope. 2013;123(8):2056-63.

3. Paschou SA, Vryonidou A, Goulis DG. Thyroid nodules: Alpha guide to assessment, treatment and follow-up. Maturitas. 2017; 96:1-9.

4. Haugen BR, Alexander EK, Bible KC, Doherty GM, Mandel SJ, Nikiforov YE, et al. American Thyroid Association Management Guidelines for Adult Patients with Thyroid Nodules and Differentiated Thyroid Cancer: The American Thyroid Association Guidelines Task Force on Thyroid Nodules and Differentiated Thyroid Cancer. Thyroid. 2016;26(1):1-133.

5. Wharry LI, McCoy KL, Stang MT, Armstrong MJ, Lebeau SO, Tublin $\mathrm{ME}$, et al. Thyroid nodules $(\geq 4 \mathrm{~cm})$ : Can ultrasound and cytology reliably exclude cancer? World J Surg. 2014;38(3):614-21.

6. Bartsch DK, Luster M, Buhr HJ, Lorenz D, Germer C-T, Goretzki PE, et al. Indications for the Surgical Management of Benign Goiter in Adults. Dtsch Arztebl Int. 2018;115(1-02):1-7.

7. Gharib H, Papini E, Paschke R, Duick DS, Valcavi R, Hegedüs L, et al. American Association of Clinical Endocrinologists, Associazione Medici Endocrinologi, and European Thyroid Association medical guidelines for clinical practice for the diagnosis and management of thyroid nodules. Endocr Pract. 2010;16 Suppl 1:1-43.

8. Al-Azawi D, Mann GB, Judson RT, Miller JA. Endocrine surgeonperformed US guided thyroid FNAC is accurate and efficient. World J Surg. 2012;36(8):1947-52.

9. Moon JH, Hyun MK, Lee JY, Shim JI, Kim TH, Choi HS, et al. Prevalence of thyroid nodules and their associated clinical parameters: a large-scale, multicenter-based health checkup study. Korean J Intern Med. 2017/07/07. 2018;33(4):753-62.

10. Davies L, Welch HG. Increasing incidence of thyroid cancer in the United States, 1973-2002. JAMA. 2006;295(18):2164-7.

11. Lin JS, Aiello Bowles EJ, Williams SB, Morrison CC. Screening for thyroid cancer: Updated evidence report and systematic review for the US preventive services task force. JAMA. 2017;317(18):1888-1903. 
12. Kwong N, Medici M, Angell TE, Liu X, Marqusee E, Cibas ES, et al The influence of patient age on thyroid nodule formation, multinodularity, and thyroid cancer risk. J Clin Endocrinol Metab. 2015 100(12):4434-40

13. Lloyd RV, Osamura RY, Klöppel G, Rosay RJ. WHO Classification of Tumours of Endocrine Organs. Fourth Edition - WHO - OMS -. WHO Classification of Tumours of Endocrine Glands. $4^{\text {th }}$ ed. Lyon: IARC. 2017.

14. Asa SL, Giordano TJ, Livolsi VA. Implications of the TCGA genomic characterization of papillary thyroid carcinoma for thyroid pathology: does follicular variant papillary thyroid carcinoma exist? Thyroid. 2015;25(1):1-2.

15. Guth S, Theune U, Aberle J, Galach A, Bamberger CM. Very high prevalence of thyroid nodules detected by high frequency $(13 \mathrm{MHz})$ ultrasound examination. Eur J Clin Invest. 2009;39(8):699-706.

16. Gharib H, Papini E, Paschke R, Duick DS, Valcavi R, Hegedüs L, et al. American Association of Clinical Endocrinologists, Associazione Medici Endocrinologi, and European Thyroid Association medical guidelines for clinical practice for the diagnosis and management of thyroid nodules: Executive Summary of recommendations. Endocrinol Invest. 2010;33(5):287-91.

17. Stoian D, Timar B, Craina M, Bernad E, Petre I, Craciunescu M Qualitative strain elastography-strain ratio evaluation-an important tool in breast cancer diagnostic. Med Ultrason. 2016;18(2): 195-200.

18. Stoian D, Cornianu M, Dobrescu A, Lazăr F. Nodular thyroid cancer Diagnostic value of real time elastography. Chirurgia (Bucur). 2012;107(1):39-46.

19. Cantisani V, D’Andrea V, Biancari F, Medvedyeva O, Di Segni M Olive M, et al. Prospective evaluation of multiparametric ultrasound and quantitative elastosonography in the differential diagnosis of benign and malignant thyroid nodules: preliminary experience. Eur J Radiol. 2012;81(10):2678-83.

20. Dudea SM, Botar-Jid C. Ultrasound elastography in thyroid disease. Med Ultrason. 2015;17(1):74-96.

21. Cosgrove D, Barr R, Bojunga J, Cantisani V, Chammas MC, Dighe $\mathrm{M}$, et al. WFUMB Guidelines and Recommendations on the Clinical Use of Ultrasound Elastography: Part 4. Thyroid. Ultrasound Med Biol. 2017;43(1):4-26.

22. Stoian D, Ivan V, Sporea I, Florian V, Mozos I, Navolan D, et al. Advanced Ultrasound Application - Impact on Presurgical Risk
Stratification of the Thyroid Nodules. Ther Clin Risk Manag. 2020; 16:21-30.

23. Dean DS, Gharib H. Fine-Needle Aspiration Biopsy of the Thyroid Gland. In: De Groot LJ, Chrousos G, Dungan K, Feingold KR, Grossman A, Hershman JM, et al., editors. South Dartmouth (MA); 2000.

24. Cibas ES, Ali SZ. The 2017 Bethesda System for Reporting Thyroid Cytopathology. J Am Soc Cytopathol. 2017;6(6):217-222.

25. Stoian D, Borcan F, Petre I, Mozos I, Varcus F, Ivan V, et al. Strain elastography as a valuable diagnosis tool in intermediate cytology (Bethesda III) thyroid nodules. Diagnostics (Basel). 2019;9(3):119.

26. Alexander EK, Pearce EN, Brent GA, Brown RS, Chen H, Dosiou C, et al. 2017 Guidelines of the American Thyroid Association for the Diagnosis and Management of Thyroid Disease During Pregnancy and the Postpartum. Thyroid. 2017;27(3):315-89.

27. Ulusoy B. The Management of Thyroid Nodules. Turkish Arch Otorhinolaryngol. 2015/12/01. 2015;53(4):173-82.

28. Patel KN, Yip L, Lubitz CC, Grubbs EG, Miller BS, Shen W, et al. The American association of endocrine surgeons guidelines for the definitive surgical management of thyroid disease in adults. Ann Surg. 2020;271(3):e21-e93.

29. Yi KH. The Revised 2016 Korean Thyroid Association Guidelines for Thyroid Nodules and Cancers: Differences from the 2015 American Thyroid Association Guidelines. Endocrinol Metab (Seoul. 2016; 31(3):373-378

30. Pellegriti G, Frasca F, Regalbuto C, Squatrito S, Vigneri R. Worldwide increasing incidence of thyroid cancer: Update on epidemiology and risk factors. J Cancer Epidemiol. 2013;2013: 965212.

31. Hong $Y$, Wu $Y$, Luo Z, Wu N, Liu X. Impact of nodular size on the predictive values of gray-scale, color-Doppler ultrasound, and sonoelastography for assessment of thyroid nodules. J Zhejiang Univ Sci B. 2012;13(9):707-16.

32. Staniforth JUL, Erdirimanne S, Eslick GD. Thyroid carcinoma in Graves' disease: A meta-analysis. Int J Surg. 2016;27:118-125. Epub 2015 Nov 26

33. Giulea C, Enciu 0, Toma EA, Martin S, Fica S, Miron A. Total thyroidectomy for malignancy - is central neck dissection a risk factor for recurrent nerve injury and postoperative hypocalcemia? A tertiary center experience in romania. Acta Endocrinol (Buchar). 2019;5(1):80-85 